TITLE: CONDUCTOR QUALIFICATION TESTS FOR THE 30-MJ BONNEVILLE POWER ADMINISTRATION SMES COIL

\author{
AUTHOR(S): $\quad$ R. I. Schermer, H. J. Boenig, \\ M. Henke, and R. D. Turner \\ Los Alamos Scientific Laboratory \\ and \\ R. Schramm \\ National Bureau of Standards \\ SUBMITTED TO: Applied Superconductivity Conference, \\ Santa Fe, NM, September 29-0ctober 3, 1980
}

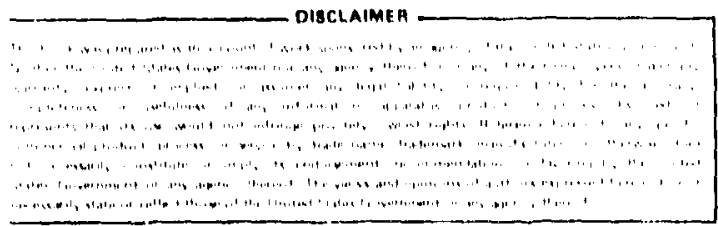

By ecceptence of this erticle, the publisher recognizes that the U.S. Government reteins a nonexclusive, royalty. Ires lloene to publish or reproduce the published form of this conertbu. tion, or 10 allow othen to do 10 , for U.S. Goverment pur. ,owes.

The Los Alemos Scientilic Leboratory requeste that the pub. lisher identily this article as work porformed under the ous. pices of the U.S. Oepartment of Eneroy.

\title{
MASTER
}




\section{CONDUCTOR QUALIFICATION TESTS \\ FOR THE \\ 30-MJ BONNEVILLE POWER ADMINISTRATION SMES COIL*}

R. I. Schermer, H. J. Boentg, M. Henke, and R. D. Turner

Los Alamos Sclentific Laboratory

Los Alamos, NM 87545

and

R. Schramm

National Bureau of Standards

Boulder, $\mathrm{CO} 80303$

\section{Summa ry}

The 30-MJ energy storage coll for the Bonnedille Power Administration requires a low-loss, sryostable conductor that 18 able to carry $4.9 \mathrm{kA} 1 \mathrm{n}$ a fleld of $2.8 \mathrm{~T}$ and will maintain $1 \mathrm{ts}$ properties over $10^{8}$ partial discharge cycles. The miti-level cable which satisfies these requirements has been extensively tested at various stages in 1 ts development and in 1 ts f Inal form. Tests have been performed to determine the effect of manufacturing options on ac losses, low temperature electrical resistivity, otabllity, and fatigue resistance of the insulated conductor. This paper will concentrate on the stabllity and fat lgue tests which have not previously been reported.

\section{Int roduct ton}

The final set of tests, undercaken to insure that the conductor for the 30-MJ System Stabllizing Magnet for the Bonneville Power Administration (BPA) will perform as specifled, is described. Deslgn requirements for the conductor are set by the coll performance, Table I. The conductor conflguration is shown in Fig. I and specteled in Table Il. Previous publer-

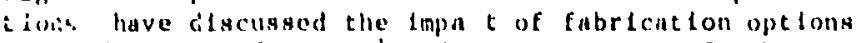
on conductor performancel and measurement of the ne lons chanateristice of this conflguratlon.? Described here are aiabllity tasta which show that the conductor, an mounted in the coll, wlll be cryoutable at a current of $7 \mathrm{kA}$, well above the requlted $5 \mathrm{kA}$. purther tests, also descilbed, show that the conductor, and parteularly the Mylur tape electrical Ineulat lon, will withetand the requlred number of lond eycles. Information in alao presented on acesptance testing for copper ard superomductor.

TABI.L: 1

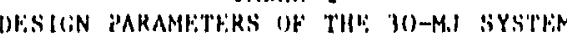
STAHII,ZINC; SMES IJN!

Maximin pewer inplobllty, MW

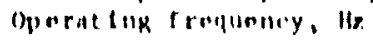

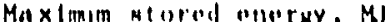

Intefichunge enwryy, $M$

Coll current at rull elarge, kA

Maxtmim roll termlinal villakn, kV

(i) Il operat Ink tempentalura, $K$

(io: I llfet lom, ryelan

Hent lond ne 4.5 K, W

Mend roll al atmetot, m

10

1,13

30. 11

9.1

4.9

$2.1 \mathrm{~h}$

4.5

$>(1) 11$

(1) 10

1.0

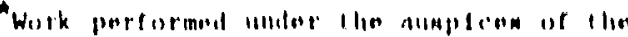

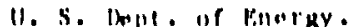

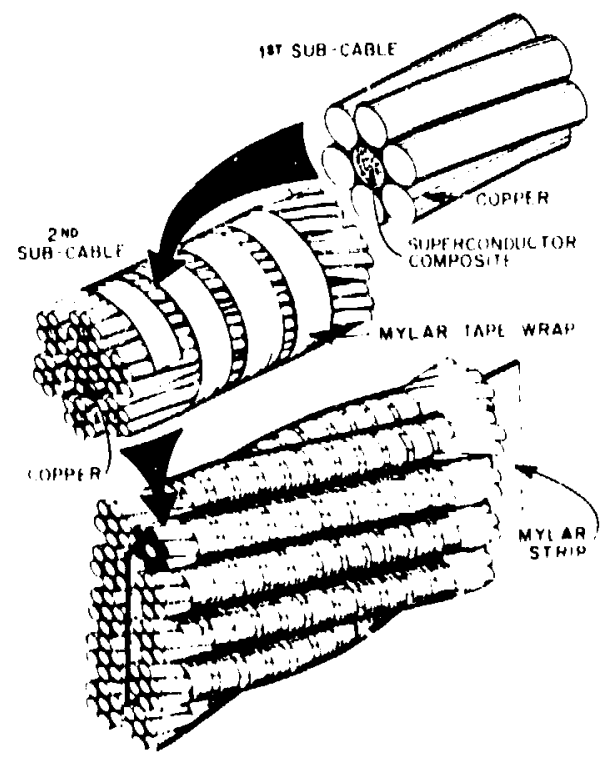

Hig. 1. Low-lone crioglable canle for jo-ilJ coll

TABLE II

CONDUCTOR SPECIPLCATIONS FOH BO-MJ GOIL.

A. Superenductor Gomponter coro

Aron of NbTl, mm²

Plamelle diancter, um

Nurber of 1 linmente

St rund dlannitur,

(it (1) Nbit ratio

IWIHe pltih, mm

B. Hiret subrablo

(six copper witere rabled

abest (nile enre)

Uncompactod dlaneler, mom

Compactod d lamelor, in

Ovarall cull lo Nbetl ralla

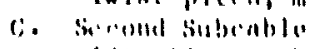

(aix lient mubeablen around

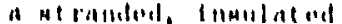

(oplener (․)

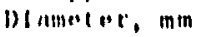

Twlal pllah, mm, and Nlencllat

lanulat lon tyun

lomulal fon a fro, mo

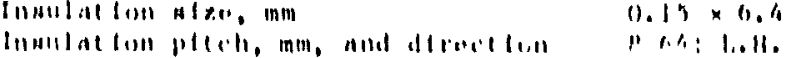

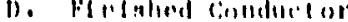

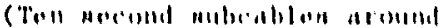

"Mylar al $r(p)$

st rll dlmentinli, mm

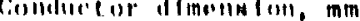

Twlat pllah, mm, alld dlrentolot
$1, \times 0.24$

$4.85 \times 10^{-2}$

6. 5

$2.94: 1$

3.1

1. 5.

$20.7: 1$

13. 5; i..11.

4.11

1h. $4: k .11$.

Mylar, adlest tve

2(1): 1..11. 


\section{Qual1ty Control and Acceptance Tests}

To ccnstruct the coll we purchased $6.4 \times 10^{\mathrm{b}}$ m of superconducting composite core from Magnetic Corporation of Amerlca. Spectfications called for the wire to carry at least $110 \mathrm{~A}$ at $4.2 \mathrm{~K}$ and $3.0 \mathrm{~T}$ as measured at a sensitivity of $1 \times 10^{-12} \mathrm{\Omega}-\mathrm{cm}$, which would cause the poorest plece of wire to operate at $80 \%$ of specification along the load 11ne. The wire as recelved carried $(125 \pm 11)$ A under specifled conditions, as measured on 64 random samples.

A compacted first subcable requires 5.04 times as much copper as composite core. Accordingly, we purchased $3.5 \times 10^{6} \mathrm{~m}$ of $0.511 \mathrm{~mm}$ PDOF copper wire. W1re as recelved and re-annealed had a RRR of $321 \pm 25$, as measured on 21 samples at $4.0 \mathrm{~K}$. Af ter compaction, the first subcable mist be arnealed at $325^{\circ} \mathrm{C}$ for $2 \mathrm{hr}$; temperature of $300^{\circ} \mathrm{C}$ produces inadequate annealing and a temperature of $350^{\circ} \mathrm{C}$ will begin to damage the superconductor. As a $Q \mathrm{C}$ measure, one sample from each annealing lot will be subjected to critical current and RRR tests for comparison with the initial values.

\section{St ab111ty Tests}

\section{Fxperiment}

Preliminarf experiments had Indicatod that relactuely small gaps in an Insulating wrap on a cable were very affective in permitting heat transfer to the liquid hellum. Mylar strip, 0.25-in. wide, 0.005-in. thick, perforated with two staggered rows of $1 / 16-1 \mathrm{n}$. holes on $1 / 8-1 n$. centers, appeared to provide sufficleat ve.tilation while simulaneously preveiting accidentill contact between second subcables. Much of the dati presented here were taken using such lnsulation. As a result of thase measurementy, it is felt that the advantige of perforated strlp is not enough to overcome the anrige addltional expense of perforition and the fabrication problems produced by the lack of adhestve on the strip. Therefore, additional runs, including that on the ' kA conductor tterelf, were performed us lng unperforiled, ndhestve backed, 0.005-1n. thlck, 0.25-111. Wide, Mylir Lapa.

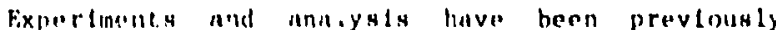
deicrlbed in detall.3 In the mi jorlty of teats, the a umplo constated of n 10-to-15 meter length of yecond

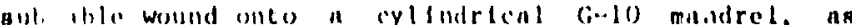
aliewil in Fig. 2. Fxcept for the $15^{\circ}$ angle which the necoul rubcibles incke with the conductor axis in Fik. 1, the goumetry of fik. 2. clonely almulated the heat tranafer anviroument of the cablea an they are mounted in the 30-M.) coll. The anple length was

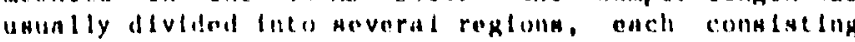
of flve turng around the maturel and ench ut llelng a

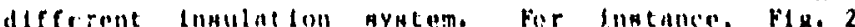
aliewa a aecelon of bare cable la the lewest reglon, a

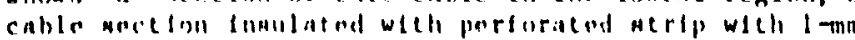
gaipe to the croteral rexton, and a cable nectlon

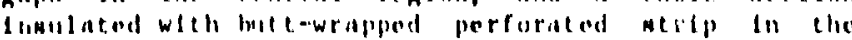

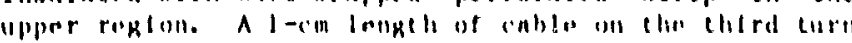
of nach reglon wan wraphed wleh at, $H-a$ heater forined of metal fllm lamblented beswroll kapton at rlpk. Vollenge

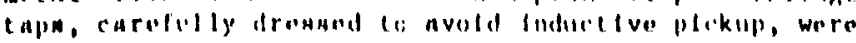

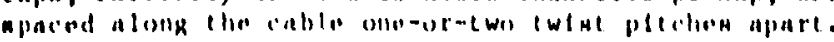

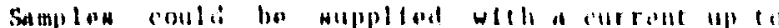

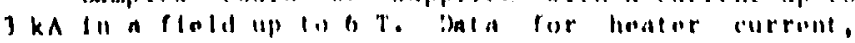

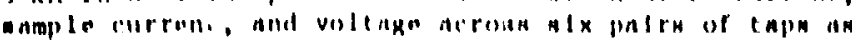

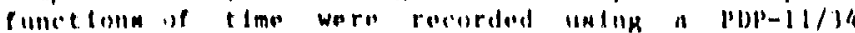

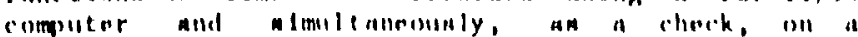

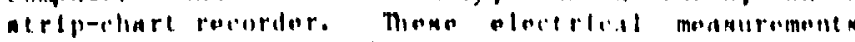

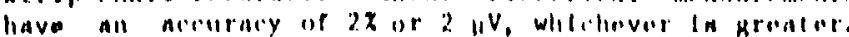
The prlinary qualit ley of la! oreat wat llie ropuvery ent-

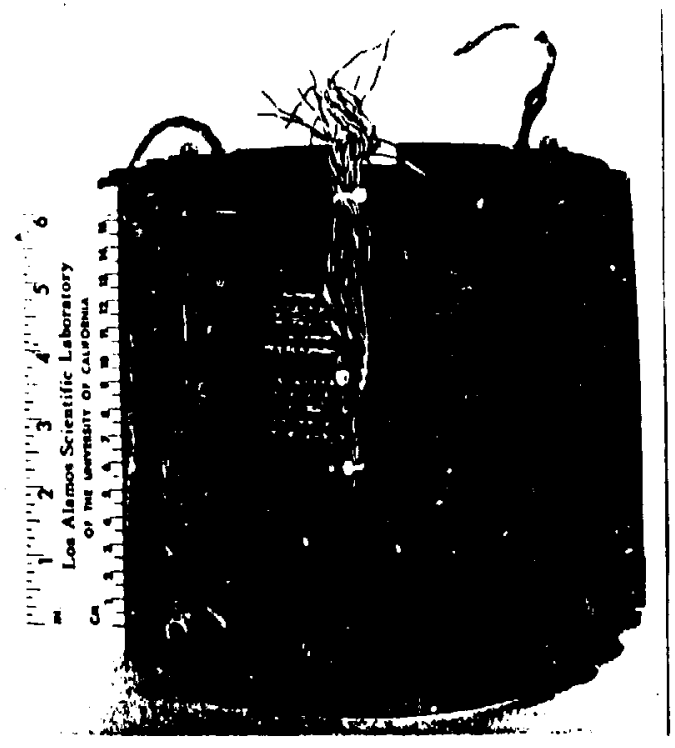

F1g. 2. Test assembly for second subcable in simulated $30-M J$ geometry. Three support strips and a surrounding Mylar shell have been removed for clarity.

rent, defined as the largest current for which a normal $z$ one would recover when the heater power was removed. The healer was typically energlaed for 5 s at a power level approximately $10 \%$ Larger than that requiled to form a mensurable normal zone. Recovery currents are usually defined within $\pm 25 \mathrm{~A}$.

A number of anomalles previously noted ${ }^{3}$ in experiments on cabled conductors were resolved by noting that our heater arrangement affects the six first subcables In a very unequal manner. Since, at a current below the recovery current, the length of a normal zone depends largely upon the heater input, the normal zones In the first subcables extend very different dictances from the heiter. The measured transverse olectrical reststivity2 is amall enough to permit oufficlent current shartag among the flrst subcables, but the corre sponding thermal reststance is large ensugh to permit these unequal zollen to persist. Thus, if alit the voltage taps are 10 t on the same first subcable, curloui patterne of voltage veraus heater power may appenr, lncluding an apparent left-right asymmetry with reapoct to the heater. Even wlth the present precallclon of attachlng all voltage tapa to the same flrst nubcable, the voltage patcurna are not minple to interprot. For Instance, we observe strong current cranger effecte as Individual firts subcablen carry, over short destances, currentes well above or bolow the nurrage value.

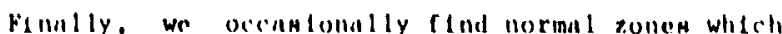

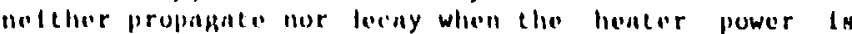
removed. Such gomes are alwaye centered on the healer,

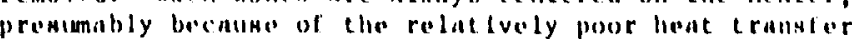
In this reglon, and defplay unusual values of vollage per unte longeh, Indlent ling unbulanced curtente. Thene

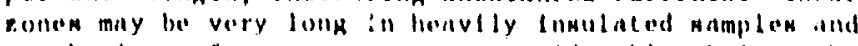
may bekli to form at a cuirent constlernbiy below the

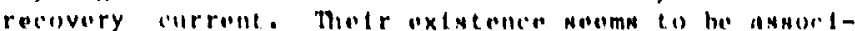

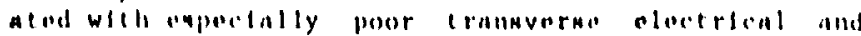

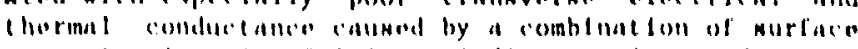

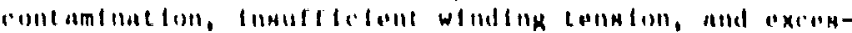
m Ivoly lonk lwiat plech. Abuve the recovery current,

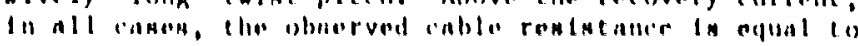


that expected from an independent RRR measurement, a fact which verifies that a true propagating zone has been observed.

\section{Results}

Fig. 3 presents data on recovery current versus fractional coverage of perforated strip, for the sample geometry of Fig. 2, at three different fields. Fractional coverage is calculated using only the gap between suc essive turns of strip and does not laclude the $20 \%$ open area due to the perforations. The rost striking feature of this data is the relatively small effect of what is, after all, a rather hefty layer of insulation. It should be noted that all recovery currents at $2.8 \mathrm{~T}$ are well above both the $30-\mathrm{MJ}$ operating current of $490 \mathrm{~A}$ per second subcable and the critica current, $750 \mathrm{~A}$ at $1 \times 10^{-12} \mathrm{\Omega}-\mathrm{cm}$. Th, points in Fig. sinter more than would be expected from experimental statistics, due to unavoldable varlation in insulation pitch and cable mounting among samples.

The same data are replotted in Fig. 4 as recovery heat flux, $q_{R}$, versus fractional coverage, where $q_{R}=I^{2} \rho / A P$. Here, I is the recovery current, $\rho$ the measured resistivity, and $A$ the copper area of the second subcable, lgnoring the copper core which was disconnected so as not to carry current. For uniformity in presenting the data, $P$ was taken as the perimeter of $\mathrm{s} 1 \mathrm{x}$ flrst subcables, each treated as is round wire $1.37 \mathrm{~mm}$ in diameter. This, presumably, grossly overestimates the wetted perimeter and thus makes the absolute heat flux values small compared with those of other workers. Experimental scarter obscures any dependence of $q_{p}$ on magret ic fleld; the data are consistent with a decrease of $10 \%$ in $q_{B}$ between zero and $3 \mathrm{~T}$ observed by Wollan et al. 4 for bare wire as

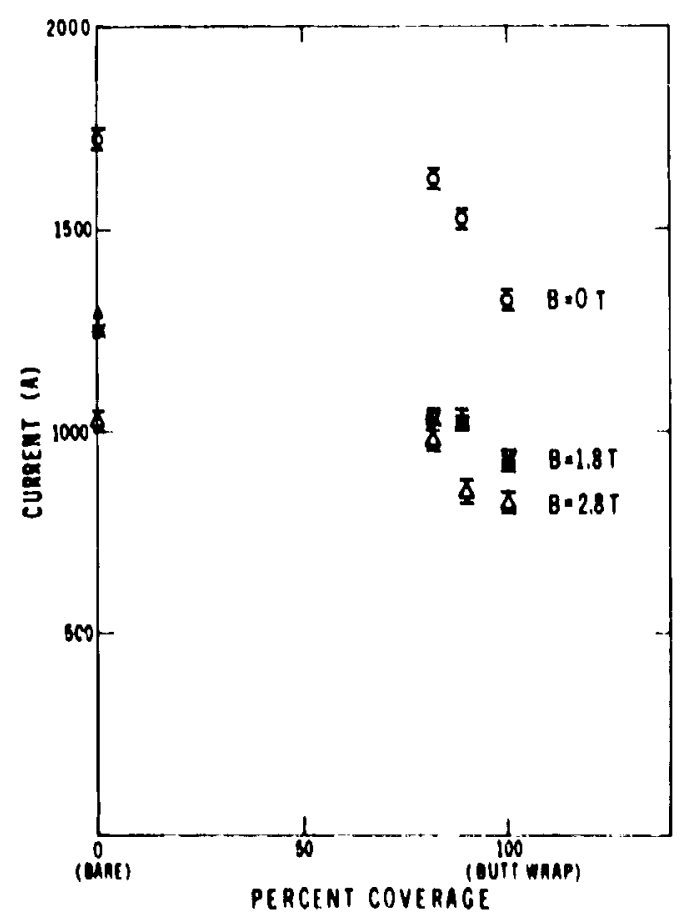

Fla. 3. Recovery current lil hecond level coble va. percentage of coverage wlth perforatod etrlp. Simulated BlA keomet ry.

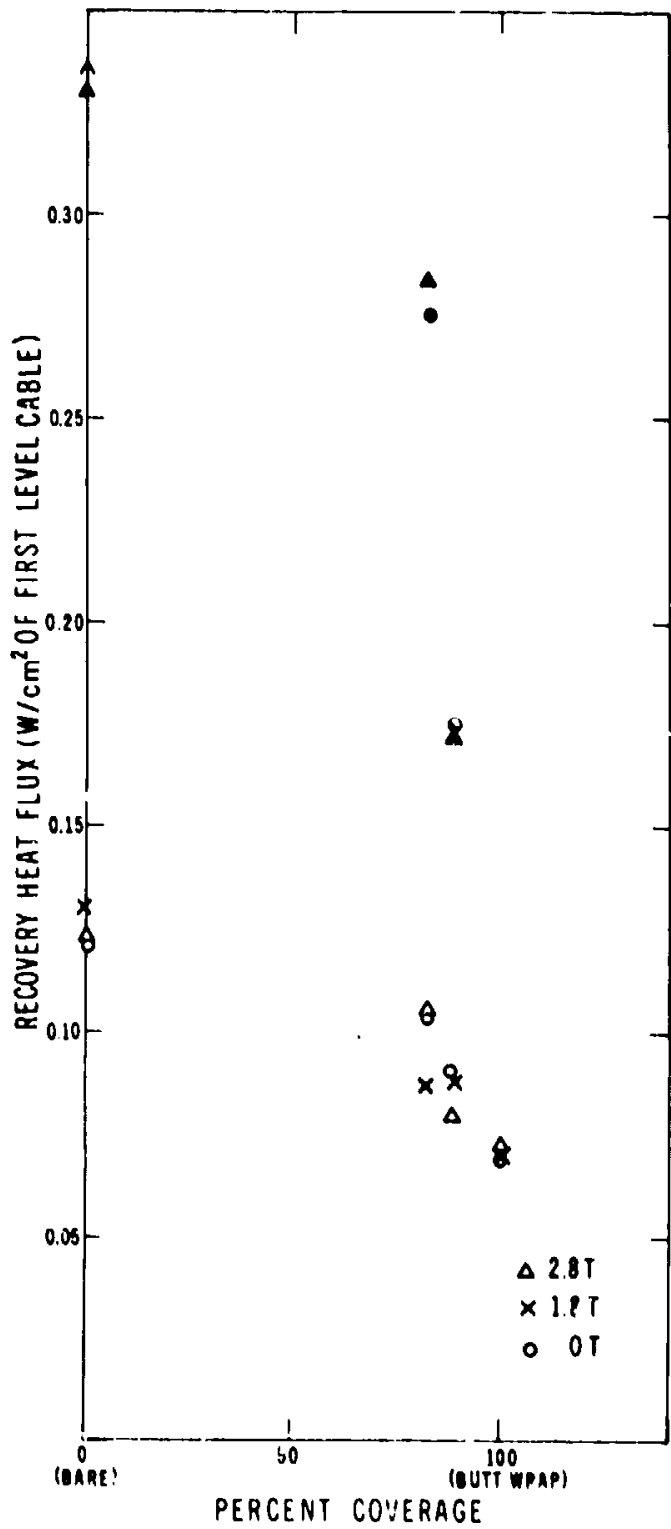

Hig. 4. Hecovery heal flux per first level cable VN. percelltige of coverage with pertorated serlp. Madiuged on socond level cable. Open polnte - elinulited BPA qeometry; Holld polnte -- open goometry.

Well an wlre linulated with a thln layer of cmega or thlick wripllak of nylon roving.

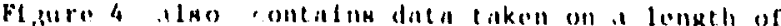
Insulated recond wubeable mounted ln no "onere keomet ry" chat provided maxlmum heslim aceone to the namplo. In

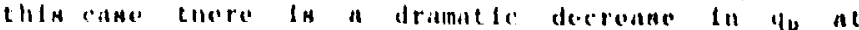

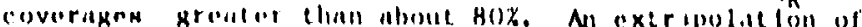
the data loade to the confecetere that the recenvery cer-

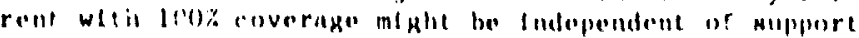

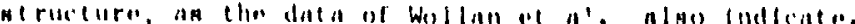
Thus, the recovery heat flux le afrected at ronstly by

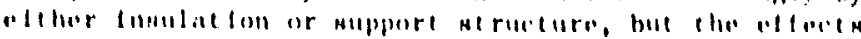

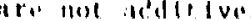


Tests on 0.005-1n. thick unperforated Mylar tape were run only at $88 \%$ coverage, that 1s, $0.040-1 n$. gaps between turns of $0.25-1 n$. wide tape. Results are summarized in Fig. 5 in which selected polnts from Fig. 4 are repeated for comparison. Experiments using the geometry of Fig. 2 were only sufficient to establish a lower bound for $q_{R}$, while experiments on the $5 \mathrm{kA}$ conductor itself better served to establish $\mathrm{q}_{\mathrm{R}}$.

In a final test, a 7 - 1 length of pre-producticn, 5-kA conductor, with the second subcables soldered together at the ends to form a bifllar sample, was wound in a single layer on a modified version of the G-10 mandrel and fitted with support teeth and insulating strips to match the actual heat transfer e..vironment in the $30-\mathrm{MJ}$ coll. It was posslble to heat a single second subcable or all ten subcables simultaneously. The latter case should correspond more closely to the arrangement of $\mathrm{Fig} .2$, in which all five nelghboring turns are Hriven normal when the zone propagates. When a single second subcable was heated, no normal zones were observed in neighboring strands unt 11 , at a current rather larger than the recovery current for the heated strand, the zones were able to propagate thru the solder jolnts between the second subcables. It 18 thus possible not only to drive a single strand normal in a cabled conductor but for it to renaln normal without affecting the other subcables. The recovery heat flux for the single subcable case was

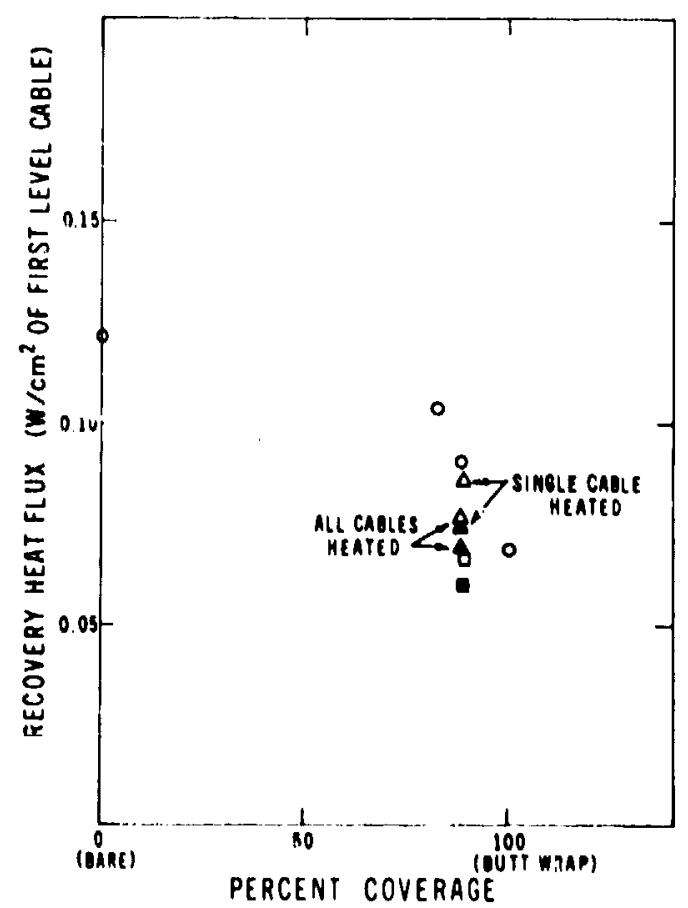

Flg. 5. Recovery heite flux por Clest lovel inble VA. Prerentiage of thio coverage for alt-

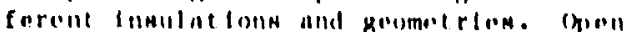
polnen - zoro rloldi clomed polnte 2. H T. Carclon aro for hocomel lovel ablo. wlth pariorated heplp Ineulatlon and almHlated HPA geomet ry; nduares - anme excent

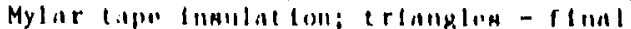
comlactor wlth Mylar inpe and raillatlo heat tranafor knesmetry. about $15 \%$ larger than that for the case with all subcables normal.

Results for perforated and unperforated insulation are consistent when plotted on the basis of total covered area.

\section{Radial Fatigue Test}

Mechanically, the weakest part of the conductor is the Mylar insulation. To control ac losses, it is 1 mortant that shorts not develop between secono subcables during the coll lifetime. The only significant cyclic load applied to the conductor is radlal compression, that is, pressure normal to the wide face. Calculations show that the mc:t highly stressed region is in the thirteenth turn at the axial midplane, with the stress depending on the transverse modulus of elasticity of the conductor. Calculated values range from $200 \mathrm{psi}$ if $\mathrm{E}=1.3 \times 10^{4} \mathrm{psi}$ to $420 \mathrm{psi}$ if $E=2 \times 10^{5} \mathrm{ps} 1$. The measured conductor modulus depends to a large extent on mechanical history, because there is a certain amount of "lost motion" in th. as-fabricated material. Preliminary measurements indicate a value of $E=2 \times 10^{4} \mathrm{ps} 1$, so that a test based on $E=2 \times 10^{b} \mathrm{psi}$ should be conservative. Cycllc loading at $4^{\circ} \mathrm{K}$ can be conducted at a rate of $-500,000$ cycles per day, and it is necessary to use a larger load at $10^{6}$ cycles to simulate the effect of $10^{t}$ cycles. A study of existing data between $10^{5}$ and $10^{6}$ cycles for stecl, copper, cloth-based-phenolic, and lass-based-epoxy indicates that a stress multiplier of 1.5 should conservatively cover the worst case. Therefore, 1t was decided to cycle the test sample between a maxlmum stress of $1.5 \times 420=630 \mathrm{ps} 1$ and $a$ minimum etress of $2 / 3$ this value.

The sample was a full-scale coll sectlon, 4 turn high in the axial direction, 2 turns thick in the radial direction, and 4 in. long. Electrical leads, at ached to all of the second subrables in suven out of elght conductors, were continuously monitored bor inter-cable shorts as the sample underwent $1.1 \times 10^{\circ}$ stress cycles whlie immeryed in liquid hellum. No shorts were developed in this process and no damage was observed when the sianplo was disassembled.

\section{Conclintons}

The $5 \mathrm{kA}$ conductor shicwn In Fig. I meots or excerds all electrical and mechanteal requiremente for the 30-NJ coll. Stiblllty teats show (a) shatll gaps la nil otherwlye thlek lnsulating layer are very effective In vent llatlus " cabled combluctor, (b) perforated inpe Is an eyolvalont method of provillag open area, (a) the cffecte of support atrueture and tape lasulation on recovery beat flux are not addlelve, and (a) it in

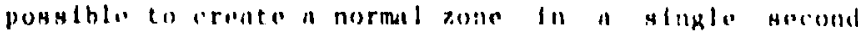

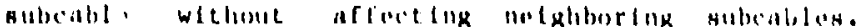

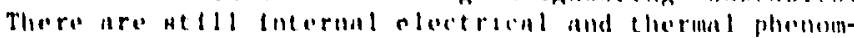

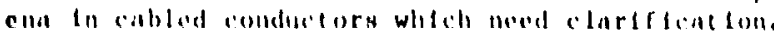

\section{Kal rerencens}

1. M. D. Henka and R. I. Schermer, Pros, kifhill symp.

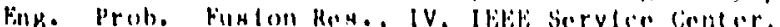

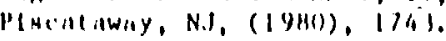

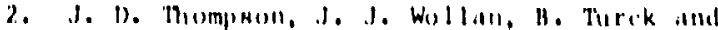

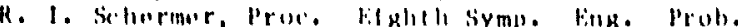

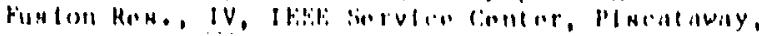
N.I ( I IH(1)), I 7 j9,

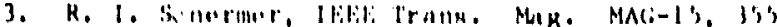
$(1419)$.

4. I. I. Wollan, M. S. Walkar and B. .1. \%, 111111, Paner

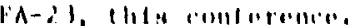

